\title{
Assessment of performance of potato crop under modified microclimates in rice based cropping system of Upper Brahmaputra valley zone of Assam
}

\author{
M. PANGING, P. NEOG ${ }^{1}$, R. L. DEKA and K. MEDHI ${ }^{2}$ \\ Department of Agrometeorology, Assam Agricultural University, Jorhat-785013 \\ ${ }^{1}$ Department of Agrometeorology, B. N. College of Agriculture, Biswanath Chariali-784176 \\ ${ }^{2}$ Regional Research Station, Gosaigaon, Assam Agricultural University, Gosaigaon 783360 \\ (e-mail: neogprasanta@rediffmail.com)
}

\begin{abstract}
A field experiment was conducted during rabi, 2017-18 in Assam Agricultural University, Jorhat to identify appropriate adaptive strategies for combating ill effect of heat and moisture stress through modifying microclimate in rice-potato double cropping system. The potato variety - Kufri Jyoti was planted in split plot design with 3 dates starting from 10 November at 10 days interval (main plots) and three mulching treatments with water hyacinth, black polythene and without mulching (sub-plots) following recommended agronomic practices. The study revealed that there were 11.8 and 7.0 per cent increase in average soil moisture content under water hyacinth and black polythene, respectively as compared to non-mulched treatment. On the other hand, soil temperature was 0.5 to $1.5^{\circ} \mathrm{C}$ (morning) and 1.1 to $2.3^{\circ} \mathrm{C}$ (evening) lower under water hyacinth, but 1.2 to $2.1^{\circ} \mathrm{C}$ (morning) and 1.7 to 2.6 (evening) higher under black polythene as compared to non-mulched crop. In all planting dates, crop growth parameters like LAI and biomass production were observed to be highest under water hyacinth, followed by black polythene and without mulching. Among the mulching treatment the highest and lowest tuber yield was recorded under water hyacinth (120.81 $\left.\mathrm{q} \mathrm{ha}^{-1}\right)$ and non-mulched treatment $\left(85.0 \mathrm{q} \mathrm{ha}^{-1}\right)$, respectively in all planting dates.It was found that the tuber yield was significantly and positively correlated (at $5 \%$ level) with the average soil moisture retention $(\mathrm{mm})$ in upper $30 \mathrm{~cm}$ layer of soil during tuber formation to physiological maturity $\left(r=77^{*}\right)$. Increase in tuber yield (up to $42.2 \%$ ) under water hyacintheven in case of late plantings (beyond 10 November) was probably due to increase insoil moisture retention (8.1 to $15.7 \%$ ) and reduction of soil temperature $\left(1\right.$ to $\left.1.8^{\circ} \mathrm{C}\right)$ under water hyacinthwhich endowed with favorable hydrothermal environment as compared to that under black polythene and non mulched treatment.
\end{abstract}

Key words: Potato, Kufri Jyoti, microclimate, mulching, moisture and temperature stress

Though growth, development and yield of potato is greatly influenced by prevailing environmental conditions, heat and water stresses are the major limiting factors for production of the crop. During initial growth stages temperature around $25^{\circ} \mathrm{C}$ is most suitable while for tuber development lower temperature $\left(<20^{\circ} \mathrm{C}\right)$ are favorable (Western Potato Council, 2003). Generally, increase in ambient temperature reduces length of growing period, increase crop respiration rates, alter photosynthate partitioning to economic produce and ultimately reduce tuber yield. Even moderately high temperature drastically reduces tuber yield without much affecting the photosynthesis and total biomass production (Singh et al., 2013). Potato is also very sensitive to water stress because of its shallow root system; approximately 85 per cent of the root length is concentrated in the upper $30.4 \mathrm{~cm}$ of the soil (Iwama, 2008) and 70 per cent of total water need is met by the crop from the upper $30 \mathrm{~cm}$ layer (Singh et al., 1987). Potato plants require a high degree of soil aeration; however, temporary dryness may reduce tuber yield. Therefore, to raise a successful potato crop, it is necessary to maintain soil moisture at the required regime of available moisture, so that soil moisture should be maintained above 65 per cent of the available soil water capacity throughout its crop growth period (Chandra et al., 2002).

One of the profitable double cropping systems identified for Assam is rice (kharif) plus potato (rabi) system which can increase the productivity of the soil to a great extent and may be a way forward to achieve the goal for doubling farmers' income (Neog et al., 2018). But soil moisture depletion and increasing soil temperature particularly in the later part of rabi season (from mid February onwards) are two major limiting factors hindering growth and yield, if planting 
of the crop is delayed beyond $15^{\text {th }}$ November (Begum and Saikia, 2014). However, modification of microclimate with respect to soil temperature and moisture regime within the root zone may provide congenial microenvironment for better growth of the crop even with higher ambient temperature. Manipulation of agronomic practices like planting times, mulching, irrigation etc may substantially modify the microclimate to affect stolonization, tuber initiation and bulking and tuber enlargement at a given site, particularly where solar radiation is not a limiting factor for potato production. In Assam, the potato is grown as rainfed crop, hence, increased variability of rainfall and temperature due to climate change is bound to affect the productivity of the crop. Under such situation, modification of microclimate through mulching and planting time can be an effective adaptation strategy for combating ill effect of heat and moisture stress on potato production, especially under rainfed condition. Since, work on micro-meteorological aspect in potato has not yet been done extensively and a few research results are available in this direction. Therefore, there is the need of studies on microclimate modification in potato to address such issues.

Mulching is a common practice used to regulate soil microclimate, mainly soil temperature and moisture (Baten $e t$ al., 1995). Mulching facilitates more retention of soil moisture and helps in controlling temperature fluctuations, improves physical, chemical and biological properties of soil, as it adds nutrients to the soil and ultimately enhances the growth and yield of crops (Baten et al., 1995; Kar 2003; Saikia et al. 2014). In addition to controlling weeds, mulching reduces daily maximum soil temperature, results in faster emergence, early canopy development and higher tuber yield as compared to no mulched crop of potato (Jaiswal, 1995). Hypothesis is that in Assam situation, mulching and manipulating planting dates will create congenial microclimate for matching growing periods to fit in the required microclimatic conditions for growth, development and yield of the crop. Keeping in view the importance of the above facts, the gaps in scientific information and the necessity of generating the field data in potato, the research was planned to evaluate the effect of mulching on soil hydro-thermal regimes in potato.

\section{MATERIALS AND METHOD}

The present field study was conducted at InstructionalCum-Research Farm of Assam Agricultural University, Jorhat, Assam $\left(26^{\circ} 74^{\prime} \mathrm{N}, 94.20^{\circ} 46^{\prime} \mathrm{E}\right.$ and $87 \mathrm{~m}$ amsl $)$ during rabi season 2017-18. The potato variety - Kufri Jyoti was planted in split plot design with 3 dates starting from 10 November $\left(\mathrm{P}_{1}\right)$ at 10 days interval (main plots) and three mulching treatments with water hyacinth $\left(\mathrm{M}_{1}\right)$, black polythene $\left(\mathrm{M}_{2}\right)$ and without mulching $\left(\mathrm{M}_{0}\right)$ (sub-plots) following recommended agronomic practices. The maximum and minimum soil temperatures were recorded with soil thermometer placed at $5 \mathrm{~cm}$ and 10 depths of soil in 9 plots of representing different treatment combinations. Soil samples from two depths, viz. 0 to $15 \mathrm{~cm}$ and 15 to $30 \mathrm{~cm}$ were collected using screw auger at 10 days interval during crop growing season. They are weighed, oven dried at $105^{\circ} \mathrm{C}$ and reweighed for estimating gravimetric soil moisture percentage and converted to the depth units by multiplying with bulk density. The observations on plant phenological stages, plant height and length of the root at harvest were taken. Plant samples for leaf area were taken periodically at 15 days interval starting from the 30 DAP. The yield samples were obtained randomly from one square meter area from each plot at two places. Tuber yield as well as number of tubers per plot was recorded. Average soil moisture retention $(\mathrm{mm})$ in upper $30 \mathrm{~cm}$ soil profile and soil temperatures under various treatment combinations of planting dates and mulching treatments in the potato cultivar Kufri Jyoti were computed and correlated with crop growth parameters and tuber yield.

\section{RESULTS AND DISCUSSION}

\section{Soil temperature variation under different microclimates}

The weekly mean morning and evening soil temperature ranged from 14.0 to $19.6^{\circ} \mathrm{C}$ and 21.0 to $28.9^{\circ} \mathrm{C}$, respectively under different planting dates and mulching treatments (Fig. 1). The highest average weekly morning and evening soil temperatures during crop period were recorded in $\mathrm{P}_{1}$ with mean morning and evening soil temperature value of 16.9 and $25.6^{\circ} \mathrm{C}$, respectively, which was followed by $\mathrm{P}_{2}$ and $\mathrm{P}_{3}$. Irrespective of dates of planting, the highest soil temperatures were recorded under black polythene (with mean value of 16.8 and $26.5^{\circ} \mathrm{C}$ in morning and evening, respectively) while the lowest was recorded under water hyacinth. The soil temperature was always 0.5 to $1.5{ }^{\circ} \mathrm{C}$ (morning) and 1.1 to $2.3^{\circ} \mathrm{C}$ (evening) was lower under water hyacinth, while it was 1.2 to $2.1^{\circ} \mathrm{C}$ (morning) and 1.7 to 2.6 (evening) ${ }^{0} \mathrm{C}$ higher under black polythene as compared to that under non-mulched condition during crop growth period (Fig. 1). 


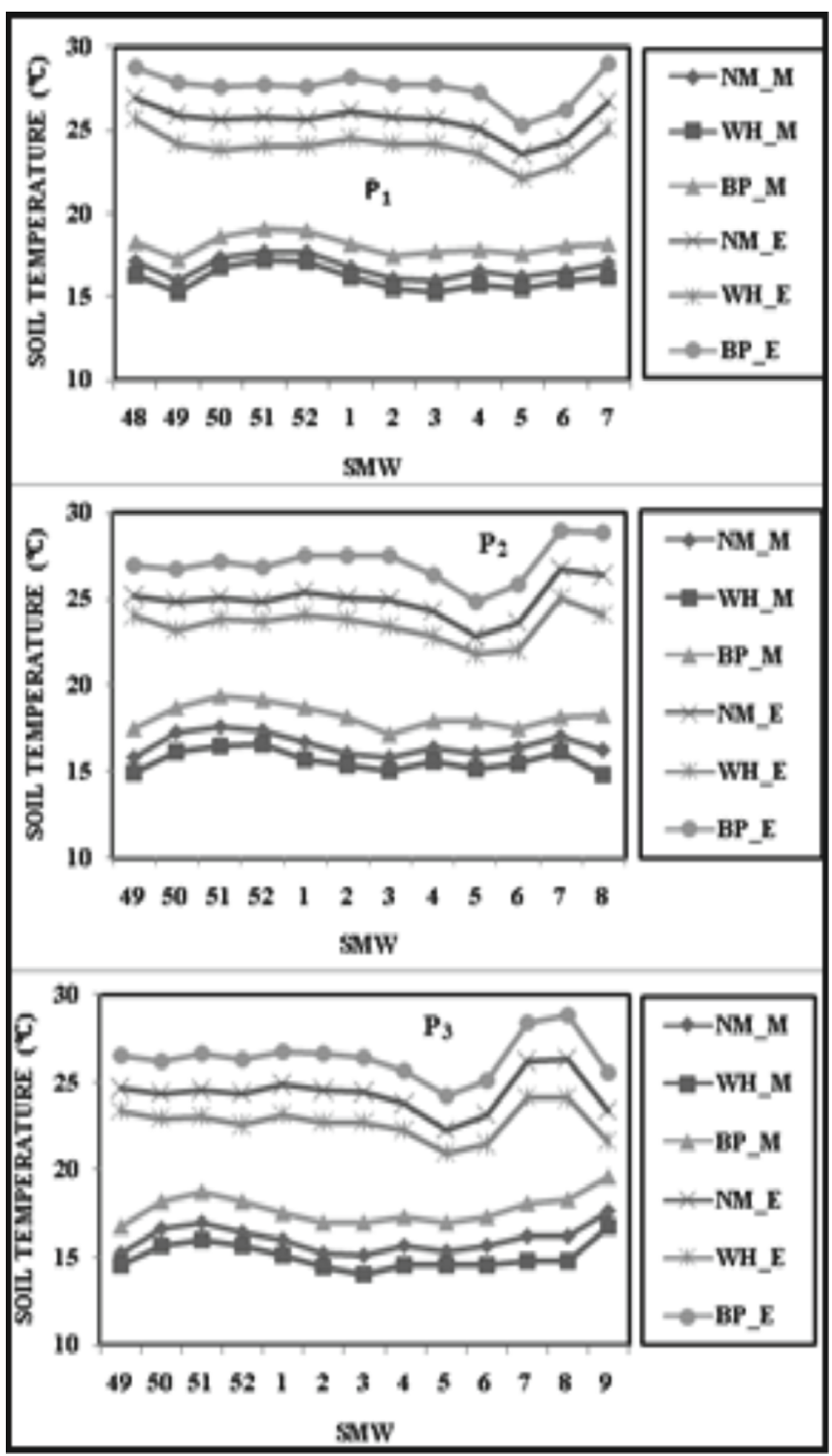

Fig.1 : Weekly mean variation of soil temperature under different dates of planting and mulching treatments in Kufri Jyoti during rabi 2017-18

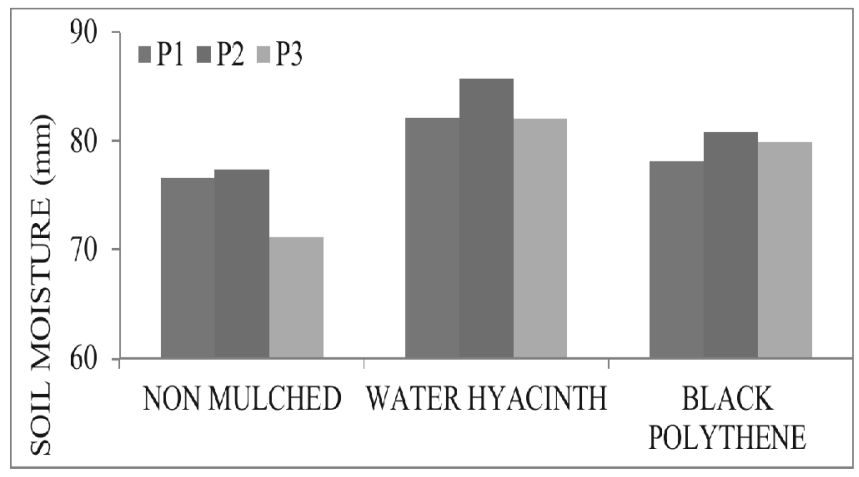

Fig. 2 : Average soil moisture retention in upper $30 \mathrm{~cm}$ soil profile during crop growth period of Kufri Jyoti under different planting dates and mulching treatment during rabi, 2017-18.

\section{Soil moisture variation under different microclimate}

Soil moisture data were taken from the upper $30 \mathrm{~cm}$ layer of soil at 10 days interval in 10 plots representing all the treatment combinations. The average soil moisture content throughout the growing season was highest in second date of planting $(81.3 \mathrm{~mm})$, followed by first $(78.9 \mathrm{~mm})$ and third $(77.5 \mathrm{~mm})$ dates of planting. The average soil moisture content throughout the growing season was highest in second date of planting $(81.3 \mathrm{~mm})$, followed by first $(78.9 \mathrm{~mm})$ and third $(77.5 \mathrm{~mm})$ dates of planting. Irrespective of dates of planting, soil moisture depth in upper $30 \mathrm{~cm}$ soil profile was highest under water hyacinth $(83.1 \mathrm{~mm})$, followed by black polythene $(79.6 \mathrm{~mm})$ and non-mulched condition $(75.2 \mathrm{~mm})$. The average soil moisture content throughout the growing season was comparatively higher under water hyacinth (11.76\%) while it was only 7.0 per cent higher under black polythene as compared controlled (Fig 2).

\section{Effect of microclimates on growth and tuber yield of Potato}

The maximum LAI, total biomass and tuber yield along with the average soil moisture retention $(\mathrm{mm})$ in upper $30 \mathrm{~cm}$ soil profile at different phenophases are presented in the Table 1. The maximum leaf area index recorded under different dates of plantings and mulching treatment ranged from 2.21 to 3.80. Irrespective of mulching treatments, the maximum LAI under different dates of planting was recorded under $\mathrm{P}_{1}(2.85)$, and it deceased gradually to 2.77 and 2.68 when planting was delayed to $\mathrm{P}_{2}$ and $\mathrm{P}_{3}$, respectively. Like dates of planting, maximum LAI of potato recoded was considerably influenced by different mulching treatments. Irrespective of dates of planting, maximum leaf area index was recorded in the crop grown under water hyacinth (3.12), followed by black polythene (2.75) and non-mulched treatment (2.42).

The biomass production at maturity was the highest in first date of planting ( $\left.379.7 \mathrm{~g} \mathrm{~m}^{-2}\right)$ and it decreased gradually in subsequent dates of planting. The maximum biomass was recorded under water hyacinth $\left(412.67 \mathrm{~g} \mathrm{~m}^{-2}\right)$, followed by black polythene (355.33 $\mathrm{g} \mathrm{m}^{-2}$ ) and non-mulched treatment $\left(289.64 \mathrm{~g} \mathrm{~m}^{-2}\right)$, irrespective of planting dates. It was observed that mean biomass partitioning towards root, leaf, stem and tuber were 3.1, 5.5, 9.5 and 81.6 per cent, respectively. Decreased in biomass production with delay in planting was probably be due to exposure to lesser sun shine duration along with lower LAI in case of crop planted on later dates $\left(\mathrm{P}_{2}\right.$ and $\mathrm{P}_{3}$ ). Increased in plant height, LAI and crop duration might result in higher biomass production under water hyacinth as compared to other mulching treatments. 
Table 1: Leaf area Index, biomass production and tuber yield of potato variety Kufri Jyoti along with average soil moisture retention ( $\mathrm{mm}$ ) in upper $30 \mathrm{~cm}$ soil profile at different phenophases of the crop during rabi, 2017-18.

\begin{tabular}{|c|c|c|c|c|c|c|c|}
\hline \multirow{2}{*}{$\begin{array}{l}\text { Dates of } \\
\text { planting }\end{array}$} & \multirow{2}{*}{$\begin{array}{l}\text { Mulching } \\
\text { treatments }\end{array}$} & \multirow{2}{*}{$\begin{array}{r}\text { Tuber yield } \\
\qquad\left(\mathrm{q} \mathrm{ha}^{-1}\right)\end{array}$} & \multirow{2}{*}{$\begin{array}{l}\text { Total biomass } \\
\qquad\left(\mathrm{g} \mathrm{m}^{-2}\right)\end{array}$} & \multirow{2}{*}{$\begin{array}{r}\text { Maximum } \\
\text { LAI }\end{array}$} & \multicolumn{3}{|c|}{ Soil moisture retention $(\mathrm{mm})$} \\
\hline & & & & & $\mathrm{P}$ to $\mathrm{TF}$ & TF to $\mathrm{PM}$ & $\mathrm{P}$ to $\mathrm{PM}^{*}$ \\
\hline \multirow{3}{*}{$\begin{array}{c}\mathrm{P}_{1} \\
\text { (Nov.10) }\end{array}$} & $\mathrm{M}_{0}$ & 92.3 & 314.3 & 2.6 & 85.4 & 67.8 & 76.6 \\
\hline & $\mathrm{M}_{1}$ & 135.6 & 445.0 & 3.2 & 88.3 & 75.8 & 82.0 \\
\hline & $\mathrm{M}_{2}$ & 110.6 & 379.8 & 2.7 & 84.1 & 72.2 & 78.1 \\
\hline \multirow{3}{*}{$\begin{array}{c}\mathrm{P}_{2} \\
\text { (Nov.20) }\end{array}$} & $\mathrm{M}_{0}$ & 82.0 & 283.2 & 2.5 & 86.0 & 68.7 & 77.4 \\
\hline & $\mathrm{M}_{1}$ & 116.1 & 408.2 & 3.1 & 92.5 & 79.0 & 85.7 \\
\hline & $\mathrm{M}_{2}$ & 100.8 & 345.4 & 2.7 & 89.2 & 72.5 & 80.8 \\
\hline \multirow{3}{*}{$\begin{array}{c}\mathrm{P}_{3} \\
\text { (Nov.30) }\end{array}$} & $\mathrm{M}_{0}$ & 80.7 & 271.4 & 2.2 & 74.9 & 68.7 & 71.2 \\
\hline & $\mathrm{M}_{1}$ & 110.7 & 384.8 & 3.0 & 88.2 & 79.0 & 82.0 \\
\hline & $\mathrm{M}_{2}$ & 99.0 & 335.7 & 2.8 & 88.1 & 72.5 & 79.8 \\
\hline
\end{tabular}

$* \mathrm{P}=$ Planting, $\mathrm{TF}=$ Tuber formation and $\mathrm{PM}=$ Physiological maturity

Table 2: Correlation coefficients of maximum LAI, total biomass and tuber yield, of Kufri Jyoti with average soil moisture retention ( $\mathrm{mm}$ ) in upper $30 \mathrm{~cm}$ of soil profile in different phenophases .

\begin{tabular}{lrrr}
\hline Variables & $\begin{array}{r}\text { Planting to tuber } \\
\text { formation }\end{array}$ & $\begin{array}{r}\text { Tuber formation to } \\
\text { physiological maturity }\end{array}$ & $\begin{array}{r}\text { Planting to } \\
\text { physiological maturity }\end{array}$ \\
\hline LAI & $0.79^{*}$ & $0.87^{* *}$ & $0.91^{* *}$ \\
Biomass & 0.64 & $0.83^{* *}$ & $0.81^{* *}$ \\
Tuber yield & 0.59 & $0.77^{*}$ & $0.74^{*}$ \\
\hline
\end{tabular}

The tuber yield $\left(\mathrm{qha}^{-1}\right)$ in all planting dates and mulching treatments varied from 80.6 to $135.6 \mathrm{qha}^{-1}$ with the overall mean of $103.0 \mathrm{qha}^{-1}$. Significant reduction of tuber yield in case of late planted crops $\left(\mathrm{P}_{2}\right.$ and $\left.\mathrm{P}_{3}\right)$ as compared to first date of planting $\left(\mathrm{P}_{1}\right)$ was probably due to lower LAI, biomass production and shorter crop growth period. Significant increase of yield under water hyacinth $(42.2 \%)$ and black polythene $(21.6 \%)$ as compared to non-mulched treatment might be due to decrease in plant height, LAI, biomass production and comparatively shorter tuber development period under non-mulched condition.

Correlation studies between tuber yield and crop growth parameters, and the average soil moisture retention $(\mathrm{mm})$ in upper $30 \mathrm{~cm}$ layer of soil profile showed that maximum LAI, total biomass production and tuber yield was significantly and positively correlated (at $1 \%$ level) with the average soil moisture content in most of the phenophases of the crop (Table 2). The tuber yield was significantly and positively correlated (at $5 \%$ level) with the average soil moisture retention $(\mathrm{mm})$ in upper $30 \mathrm{~cm}$ layer of soil during tuber formation to physiological maturity $\left(\mathrm{r}=77^{*}\right)$ and planting to physiological maturity $\left(\mathrm{r}=74^{*}\right)$.

\section{CONCLUSION}

From the field experiment it was observed that increase in soil moisture retention ( 8.1 to $15.7 \%$ ) and reduction of soil temperature $\left(1\right.$ to $\left.1.8^{\circ} \mathrm{C}\right)$ under water hyacinth $\left(\mathrm{M}_{1}\right)$ endowed with favorable crop growth environment, which was reflected in increasing of LAI, biomass production, and finally tuber yield as compared to other mulching treatments. Thus it can be concluded that microclimate modification may be a successful adaptive strategy for managing weather variability with 
respect to soil moisture and soil temperatures in potato crop grown in Assam.

\section{REFERENCES}

Baten, M.A., Nahar, B.S., Sarker, S.C and Khannn, M.A.H (1995). Effect of different mulches on the growth and yield of late planted garlic (allium Sativum L.). Pak. J.,Sci. Ind.Res, 38: 138-141.

Begum, M. and Saikia, M. (2014). Effect of irrigation and mulching on growth and yield attributes of potato. Agri. Sci.Digest., 3(1): 76-78.

Chandra, S., Singh, R. D. Bhatnagar, V.K. and Bisht, J.K. (2002) . Effect of mulch and irrigation on tuber size, canopy temperature, water use efficieny and yield of potato (Solanum tuberosum). Indian J. Agron., 47: 443448.

Iwama, K. (2008). Hysiology of the potato: New insights into root system and repercussion for crop management. Potato Res., 51:333-353.

Jaiswal, V.P. (1995). Response of potato (Solanumtuberosum) cultivars to date of planting and mulching under warm temperature condition. Indian J. Agron., 40:660-664.

Kar, G. (2003). Tuber yield of potato as influenced by planting dates and mulches. J. Agrometeorol., 5(1):60-67.
Neog P., Sarma, P.K., Borah, P, Sarma, D., Sarma M.K., Borah, R., Hazarika G.N. and Chary, G.R. (2018). Climate Resilient Agriculture - Experiences from NICRA implementation in North Bank Plains Zone of Assam. Research Bulletin (AAU/DR/18(BL)/229/2018-19), BN College of Agriculture, published by AICRPDA, Biswnath Chariali, Assam-784176.

Saikia, U.S., Kumar, A., Das, S., Pradhan, R., Goswami, B., Wungleng, V.C., Rajkhowa, D.J. and Ngachan, S.V. (2014). Effect of mulching on microclimate growth and yield of mustard under mid-hill condition of Meghalaya.J. Agrometeorol., 16(1):144-145.

Singh, P.N.; Joshi, B.P. and Singh, G. (1987): Effect of mulch on moisture conservation, irrigation requirement and yield of potato. Indian J. Agron., 32: 452-454.

Singh, B.P., Dua, V.K., Govindrakrishnan, P.M. and Sharma, S (2013). Impact of climate change on potato in climate resilient horticulture: Adaptation and Mitigations Strategies, pp. 125-135.

Western Potato Council (2003). Botany of potato plant. Adaptation from Guide to Commercial Potato production on the Canadian Prairies. Accessed on 14 April 2005. Available at http://www.agr.gov.sk.ca/ docs/crops/hortriculture/poratoManual_Botany.pdf 